\title{
Assessment of Impact of International Financial Reporting Standards (IFRS) Adoption on Financial Institutions in Nigeria
}

\author{
Joseph E. Ekpenyong ${ }^{1}$, Oludaisi T. Damilola*2 \\ ${ }^{1}$ Department of Petroleum Marketing and Business Studies, Petroleum Training Institute, Effurun, Nigeria \\ ${ }^{* 2}$ Department of Accounting, Olabisi Onabanjo University, Ago-Iwoye, Nigeria \\ *Corresponding Author: Oludaisi T. Damilola
}

\begin{abstract}
This study examines the impact of adopting IFRS on the financial statements of Nigerian depositary banks. The data used was taken from the annual report of selected banks listed on the Nigeria Stock Exchange in Nigeria from a period of 2013 to 2017. To achieve this, the panel's Ordinary least squares regression procedure was used. The results show that R-squared is 78\%. This means that the overall QFS variation is 78\%, which can be explained by the explanatory variables following the independent variable, which is sufficient to explain the dependent variable (quality of accounting information). The F-Statistic is 2.07870 and the probability value is 0.026393 with $\mathrm{p}<0.05$. This is statistically significant and means that the goodness of fit of the model is high and significant. Therefore, the model is well specified and can be estimated. A Durbin-Watson statistic of 2 was obtained. This means that the results are free of continuous autocorrelation issues. In particular, the IFRS correlation coefficient is 0.74458 and the probability value is 0.0105 with $\mathrm{p}<0.05$. This is positive and statistically significant. This shows that there is a direct and significant correlation between the adoption of IFRS and the quality of financial statements. The results revealed a positive and significant association between ROA, growth, size, age and quality of accounting information.
\end{abstract}

Keywords: International Financial Reporting Standards (IFRS); Quality of Financial statement (QFS); Return on Asset (ROA); Growth; Size of firm

\section{INTRODUCTION}

The goals of the IFRS Foundation and the IASB is to develop in the public interest, a single set of high-quality, understandable, enforceable and globally accepted financial reporting standards based upon clearly articulated principles (Adereti and Sanni, 2016). In pursuit of this goal, the IASB works in close cooperation with stakeholders around the world, including investors, national standard-setters, regulators, auditors, academics, and others who have an interest in the development of high-quality global standards (Adereti and Sanni, 2016). Providing high quality financial reporting information is important because it will positively influence capital providers and other stakeholders in making investment, credit, and similar resource allocation decisions enhancing overall market efficiency. Financial regulators in Nigeria have given 2012 as the deadline within which the Banks operating in Nigeria should migrate to IFRS from the current General Accounting Principles (GAP).

Only three banks in Nigeria started preparing their financial report according to International financial reporting standards (IFRS) before it was adopted in Nigeria in January 2012. But only these three banks have published their financial report based on International financial reporting standards (IFRS) on their websites (Abdul-Baki et al., 2014; Okpele, 2012; Onalo, 2014; Onipe et al., 2015). These three banks are Guarantee Trust Bank (GTB), First Bank 
Nigeria, United Bank for Africa. This study will focus its attention on these three banks. 


\section{Statement of the Problem}

For the purpose of uniformity and reliability, financial statements are usually prepared on the basis of certain provisions/regulatory standards and conventions in accounting. Thus, in Nigeria for instance, before the adoption of the International Financial Reporting Standards (IFRS) which was developed and issued by the Nigerian Accounting Standard Boards (NASB) and designed for use by reporting entities in Nigeria, such that a financial statement prepared in Nigeria tend to be different in terms of treatments of transactions and disclosures with those prepared under different standards in other countries of the world. It is therefore expected that with the move by Nigeria and other countries of the world to adopt IFRS, issues on accounting treatments and disclosures needed to be closely and empirically evaluated to ascertain the extent to which IFRS adoption had affected the financial reporting quality of quoted firms in Nigeria.

\section{Research Hypothesis}

The empirical analysis in this study would be based on the following hypotheses:

$\mathrm{H}_{\mathrm{ol}}$. IFRS plays no significant role in ensuring Growth of money deposit banks in Nigeria.

$\mathrm{H}_{\mathrm{o} 2}$. There is no significant relationship between IFRS Adoptions and Size of money deposit banks in Nigeria.

$\mathrm{H}_{03}$. IFRS plays no significant role in ensuring Age of money deposit banks in Nigeria.

$\mathrm{H}_{04}$. There is no significant relationship between IFRS adoptions and ROA of money deposit banks in Nigeria.

\section{LITERATURE REVIEW}

\section{The Concept of IFRS Adoption}

IFRS are accounting rules ("standards") issued by the International Accounting Standard Board (IASB), an independent organization based in London, UK. Before the inception of IASB, international standards described as International Accounting Standards (IAS) were issued by the IASB`s predecessor organization, the IASC, a body established in 1973 through an agreement made by professional accountancy bodies from Australia, Canada, France, Germany, Japan, Mexico, the Netherlands, the United Kingdom and Ireland, and the United States of America. According to the IFRS adoption Roadmap Committee (2010), Public Listed Entities and Significant Public Interest Entities are expected to adopt the IFRS by January 2012. Nigerian listed entities were required to prepare their closing balances as at December 31, 2010 according to IFRS. The opening balances for January 1, 2012 will be the first IFRS full financial statements prepared in accordance with the provision of IFRS as at December 31 (Paglietti, 2009).

\section{Benefits of Adopting IFRS in Nigeria}

The adoption of IFRS has several benefits as reported by previous studies carried out by several scholars this includes: Leuz and Verrecchiia, (2000): decreased cost of capital; Bushgmnanb and Piotroski, (2006): efficiency of capital allocation; Young and Guenther, (2008): international capital mobility; Ahmed, (2011): capital market development; 
Akinyele and Fasogbon, (2010): increased market liquidity and value; Okere, (2009): enhanced comparability; Bhatacharjee and Hossain, (2010): cross border movement of capital; Mike, (2009): improved transparency of result. The potential blessings that Nigeria stand to benefit after IFRS adoption are visible within side the mild of: merchandising of the compilation of significant information at the overall performance of numerous reporting entities at each public and personal tiers in Nigeria thereby encouraging comparability, transparency, performance and reliability of monetary reporting in Nigeria; guarantee of beneficial and significant choices on funding portfolio in Nigeria; it draws funding via extra transparency and a decrease price of capital for capability investors; guarantee of less complicated get entry to outside capital for nearby companies; discount of the price of doing commercial enterprise throughout borders with the aid of using removing the want for supplementary records from Nigerian companies; facilitation or smooth consolidation of monetary records of the equal business enterprise with workplaces in different countries (Armstrong et al., 2007; Christensen et al., 2008).

\section{Theoretical Review}

Accounting Theories point out to the scientific ways of thinking for the solution of any real world accounting problem (Bala, 2013). Accounting theory and Accounting Practices are absolutely closely related (Barth et al., 2008; Jarva and Lantto, 2012).

Institutional Isomorphism Theory: Institutional theory has been adopted in accounting literature as a valuable framework to explain the country-specific factors affecting emerging economies` decisions to permit the use of IFRS. Othman and Kossentini, (2015), explicitly stated that institutional pressure occur at the country-level as well as the firm level or the organizational-level.

The Economic theory of networks: Othman and Kossentini, (2015), supported that "there are many products for which the utility that user derives from consumption of the good increases with the number of other agents consuming the good". The economic literate sometimes calls the network related value as synchronization value (Othman and Kossentini, 2015).

\section{Empirical Review}

Yahaya et al., (2015), observes that International Financial Reporting Standard (IFRS) has become the new dominant set of accounting standards. The study likewise seeks to identify the sources of differences in financial reporting experienced by Banks due to the changes in the regime.

Adereti and Sanni (2016), in their study evaluated the impact of the adoption on the earnings quality of First Bank Nigeria Plc, one of the leading banks in the country against the background that the adoption of IFRS is expected to lead to the disclosure of more and better information which will improve the earning quality of firms. The Six (6)year study period was evenly divided into 3 years before IFRS (2009-2011) and 3 years after IFRS (2012-2014). 
Revenue returns and revenue changes were used as a substitute for revenue quality, consistent with the reviewed literature.

Adam, (2009), opined that sequel to that adoption of IFRS in Nigeria in January 2012, the urgent query agitating the minds of researchers in addition to different stakeholders in monetary reporting is whether or not the necessary adoption of IFRS has given upward push to an improved price relevance (or quality) of monetary facts in Nigeria banks. Findings found out that Book Value of Equity (BVE) and Earnings consistent with Share are definitely related to proportion price.

\section{METHODOLOGY}

In this study data from three (3) banks namely First Bank of Nigeria Plc, United Bank for Africa Plc, and Guaranty Trust Bank Plc were used. The rationale for choosing the sampled banks of this study is because they were among the first set of banks that transited from Nigerian FAAP (SAS) to IFRS. Therefore, they have more years/data for which their financial reports were prepared in compliance with the provisions of IFRS for the periods under investigation (Five years after IFRS adoption).

\section{Research design}

This study used an ex-post facto research design due to existing data on the variable in the data. It is a quasiexperimental study examining how an independent variable affect a dependent variable. Also, a quantitative method of research was adopted to develop and employ mathematical model, theories or hypothesis pertaining to the phenomena. Data on growth, size of firms, return on assets, and age of firms were obtained from the annual reports and accounts of the sampled banks for the period before and after IFRS adoption.

\section{Method of data analysis}

In this study, the panel ordinary least square regression (OLSR) was employed while paired t-test was used to compare the quality of accounting information before adoption and after adoption of international financial reporting standards.

\section{Model specification}

The model of this study assumes that quality financial reporting is a function of return on asset, growth, size of the firm, and age of firms. This is expressed as;

$\mathrm{QFS}=\mathrm{f}(\mathrm{ROA}, \mathrm{GRW}, \mathrm{SIZE}$, and AGE)

Based on this premises, the functional econometric employed is;

$\mathrm{QFS}=\beta 0+\beta 1 \mathrm{IFRS}+\beta 2 \mathrm{ROA}+\beta 3$ Growth $+\beta 4$ Size $+\beta 5$ Age $+\mathrm{e}$

Where: QFS = Quality of Financial Statement

IFRS = International Financial Reporting Standard

ROA $=$ Return on Asset 
GRW $=$ Growth

$\mathrm{SIZE}=$ Size of the firm

$\mathrm{AGE}=$ age

$\mathrm{e}=$ Error term

The apriori expectation of the variables employed in the above model is $\beta_{1}, \beta_{2}, \beta_{3}, \beta_{4}>0$.

\section{Measurement of variables:}

Independent variables: The independent variables are;

1. International financial reporting standard (IFRS) which was measured using the dummy variable (0 for non adoption and 1 for adoption).

2. Growth which is measured revenue of current year minus revenue of previous year divided by the revenue of current year.

3. Size which is measured as natural log of total asset.

4. Return on asset which is measured using profit after tax divided by total asset.

5. Age which is measured year of incorporation minus current year

6. e $(i, t)$ which is the error term,

7. $\mathrm{i}$ and $\mathrm{t}$ are used for banks and year subscripts respectively

Dependent variable: The dependent variable is the Quality financial Report which was measured using predictability values given as:

operating net profit

Net income

This suggests that the independent variables are expected to be positively associated with and also influence banks' performance in Nigeria. 
Table 1. Showing the independent variable and the apriori expectation

\section{VARIABLE}

Growth

Size

ROA

Age
PRIOR EXPECTATION

$+$

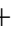

\section{RESULTS AND DISCUSSION}

In this study, descriptive and inferential statistical techniques were employed to carry out the analysis. Descriptive statistics, particularly mean, were used to gain insight into how the data were distributed. It is important to note that this data is from the 2013-2017 annual reports of these banks, as most of these banks transitioned to International Financial Reporting Standards from 2013 to 2017. The computation results are presented in Tables 2 to 4. 
Table 2. Computation from Guarantee Trust Bank (GT Bank) data

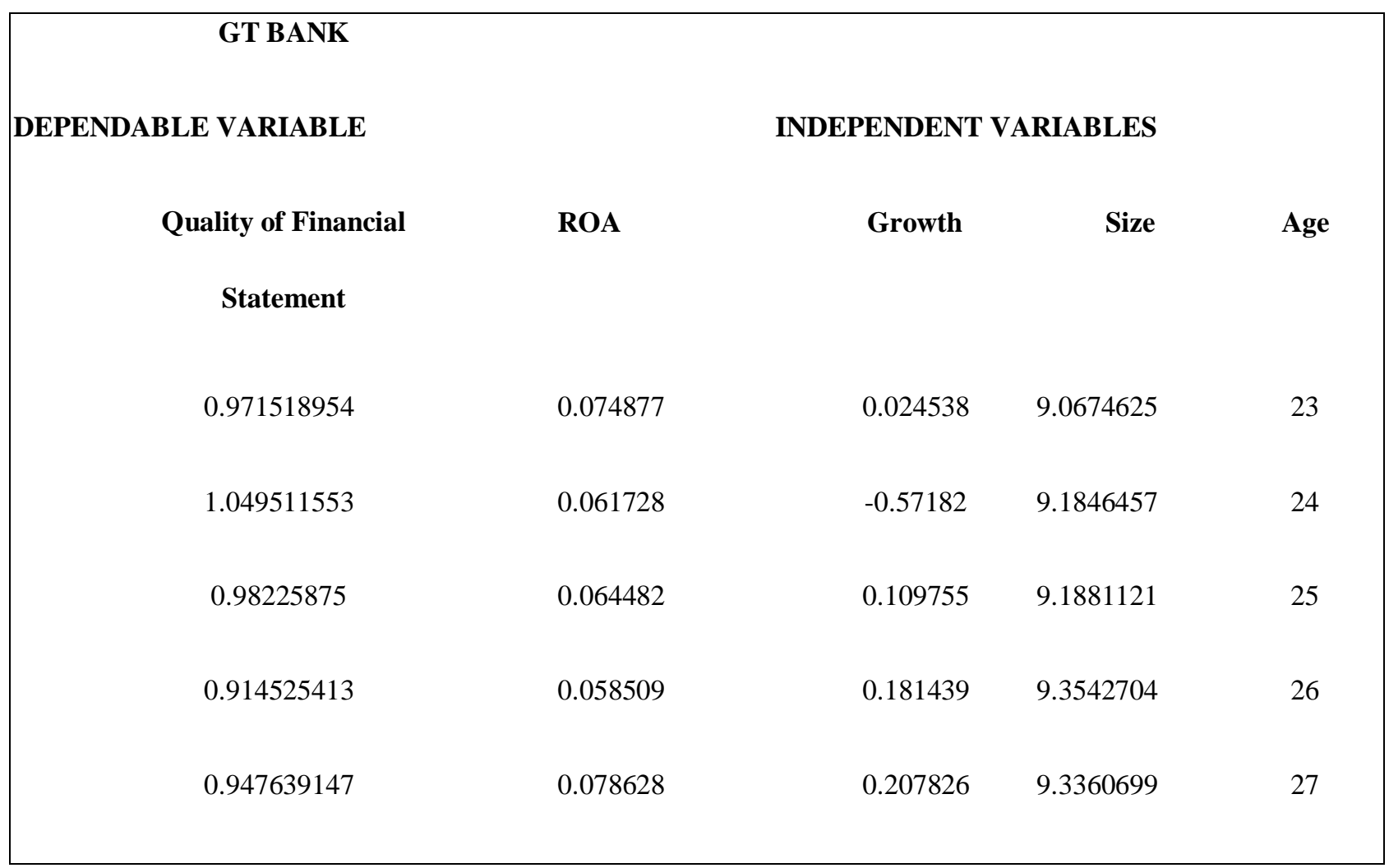

Source: Annual Reports 2013 - 2017. Author's Computation. 
Table 3. Computation from First Bank data

\begin{tabular}{|c|c|c|c|c|}
\hline $\begin{array}{c}\text { FIRST BANK } \\
\text { DEPENDABLE VARIABLE }\end{array}$ & INI & ENT VAR & & \\
\hline $\begin{array}{c}\text { Quality of Financial } \\
\text { Statement }\end{array}$ & ROA & Growth & Size & Age \\
\hline 1.031032878 & 0.028082 & -0.02516 & 9.3740788 & 119 \\
\hline 1 & 0.046138 & 0.088631 & 9.2649825 & 120 \\
\hline 0.19448112 & 0.00164 & 0.074398 & 9.2543587 & 121 \\
\hline 1 & 0.005335 & 0.149887 & 9.3607927 & 121 \\
\hline 0.971140777 & 0.011886 & 0.081684 & 9.5271591 & 122 \\
\hline
\end{tabular}

Source: Annual Reports 2013 - 2017. Author's Computation. 
Table 4. Computation from United Bank of Africa Bank (UBA) data

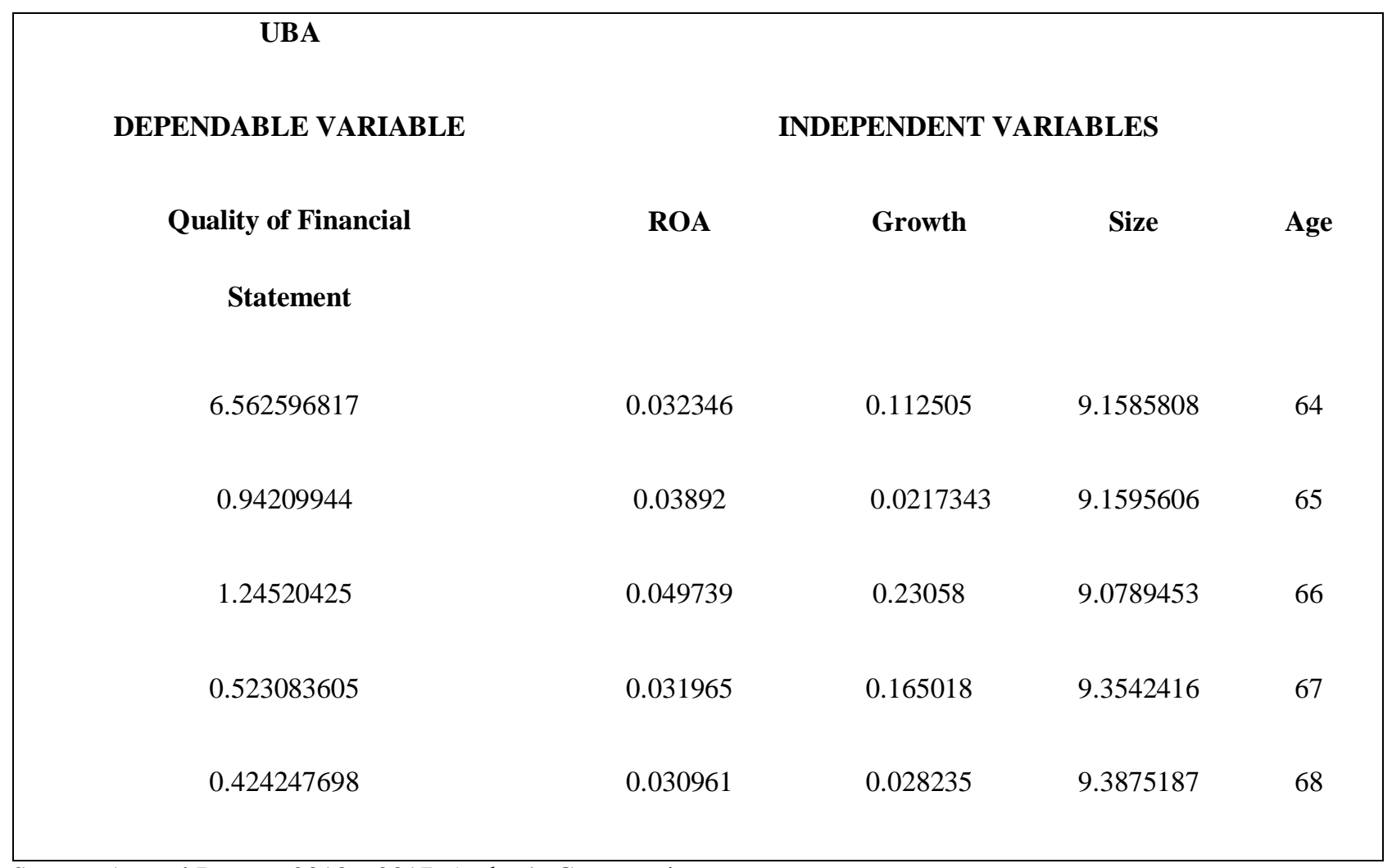

Source: Annual Reports 2013 - 2017. Author's Computation.

\section{Data Analysis and Discussion}

From Table 5 below, it can be inferred that the mean and median of the variables lie between the minimum and the maximum. This indicates the possibility of a normally distributed variable. The standard deviations for QFS, ROA, GROWTH, SIZE, and AGE are 1.494920, 0.023981, 0.189229, 0.129277, and 40.55660, respectively. All variable records are positively distorted except for ROA and GROWTH which are simply distorted. The value of the variable indicates that ROA, SIZE and AGE are less than 3, i.e. Platykurtic (their distribution has excessively negative kurtosis) and the other two variables are greater than 3 i.e. they are Leptokurtic (their distribution have positive excess kurtosis). 
Table 5. Result of Descriptive Statistics

\begin{tabular}{|c|c|c|c|c|c|}
\hline & QFS & ROA & GROWTH & SIZE & AGE \\
\hline Mean & 1.250623 & 0.041016 & 0.058991 & 9.270052 & 70.53333 \\
\hline Median & 0.971519 & 0.038920 & 0.088631 & 9.264983 & 66.00000 \\
\hline Maximum & 6.562597 & 0.078628 & 0.230580 & 9.527159 & 122.0000 \\
\hline Minimum & 0.194481 & 0.001640 & -0.571824 & 9.067463 & 23.00000 \\
\hline Std. Dev. & 1.494920 & 0.023981 & 0.189229 & 0.129277 & 40.55660 \\
\hline Skewness & 3.265476 & -0.084618 & -2.610749 & 0.094651 & 0.171012 \\
\hline Kurtosis & 12.23218 & 2.012886 & 9.561517 & 2.270005 & 1.502479 \\
\hline Jarque-Bera & 79.92906 & 0.626897 & 43.94847 & 0.355455 & 1.474719 \\
\hline Probability & 0.000000 & 0.730922 & 0.000000 & 0.837171 & 0.478375 \\
\hline Observations & 15 & 15 & 15 & 15 & 15 \\
\hline
\end{tabular}


Table 6. Summary of assessment of the impact of adopting IFRS on the quality of financial statements of Nigerian banks

\begin{tabular}{|c|c|c|c|c|}
\hline Variable & Coefficient & Std. Error & t-Statistic & Prob. \\
\hline IFRS & 0.744538 & 0.303594 & 2.616446 & 0.0105 \\
\hline $\mathbf{C}$ & 4.509492 & 3.627253 & 1.160518 & 0.2728 \\
\hline ROA & 0.002696 & 0.003518 & 0.739487 & 0.0466 \\
\hline GROWTH & 0.098862 & 2.366846 & 0.386110 & 0.0475 \\
\hline SIZE & 0.051269 & 3.895428 & 1.081388 & 0.0349 \\
\hline AGE & 3.383947 & 0.021152 & 0.512941 & 0.0691 \\
\hline \multicolumn{5}{|c|}{ Effect Specification } \\
\hline R-squared & 0.780624 & & & \\
\hline Adjusted R-squared & -0.203126 & & & \\
\hline S.E. of regression & 1.639735 & & & \\
\hline Sum squared residue & 26.88730 & & & \\
\hline f-statistic & 2.007870 & \multicolumn{2}{|c|}{ Durbin-Watson stat } & 1.932344 \\
\hline Prob (F-statistic) & 0.026393 & & & \\
\hline
\end{tabular}

The results in Table 6 above provide an assessment of the impact of adopting IFRS on the quality of financial statements of Nigerian savings banks. A five-year analysis of the three custodians listed between 2007 and 2016 was performed using the panel's ordinary least squares regression. The results show that the $\mathrm{R}^{2}$ is $78 \%$. This means that $78 \%$ of the total variation in QFS can be explained by the explanatory variables. Therefore, the independent variable is sufficient to explain the dependent variable (quality of accounting information). The F-Statistic is 2.007870 with 
probability value of 09.026393 at $\mathrm{p}<0.05$. This is statically significant which implies that the model fits well and is significant, therefore, the model is well specified and can be estimated. A Durbin-Watson statistic of 2 implies that the results are free of serial autocorrelation problem. In particular, the correlation coefficient of IFRS is 0.744538 and the probability value is 0.0105 with $\mathrm{p}<0.095$. This is positive and statically significant. This shows that there is a direct and significant relationship between IFRS adoption and the quality of financial statements. The results show that an increase in IFRS adoption by savings banks by about 79\% improves the quality of accounting information. The results also show that there is a significant and positive correlation coefficient between the adoption of IFRS and the quality of accounting information of banks in Nigeria. If the size correlation coefficient value of 0.051269 and the probability of 0.0349 , increasing the size of the company by 1 unit means that the quality of the accounting information of the selected bank is improved by $5 \%$. This shows that there is a positive correlation between the size of the company and the annual financial statements. The growth correlation coefficient value is 0.098862 and the probability of 0.4075 . This implies that a $10 \%$ increase in the size of the company will improve the quality of the financial statements of the selected bank by $10 \%$. The Age correlation coefficient value of 3.383947 and the probability is 0.0691 . This implies that one credit increase in Age will improve the quality of your degree by $338 \%$. Return on assets shows 0.002696 and probability value 0.003518 . This shows that there is a positive and significant correlation between IFRS and the quality of financial statements. The above results show that this is in line with previously stated expectations. Various journal articles have been reviewed on this, and some findings are consistent with the findings.

\section{CONCLUSION}

The study examined the effect of adoption of IFRS on the financial statement quality of money deposit banks in Nigeria. The study finds that there is a significant and positive relationship between financial statement quality and the adoption of IFRS. The study therefore concludes that the adoption of IFRS affect the financial statement quality of money deposit banks positively. The study used a panel data analysis of three (3) banks selected in Nigeria for 10 years and sought to contribute to knowledge using four variables: IFRS, growth, age, return on investment, and size.

\section{RECOMMENDATION}

It is recommended that the financial reporting council, as a main control and regulatory authority for IFRS compliance in Nigeria should be strengthened and made independent. Nigerian companies should integrate their businesses in the global village by getting listed in the international financial market for easy practice of IFRS.

\section{ACKNOWLEDGEMENT}

The authors profoundly acknowledge the management of the Central Bank of Nigeria for providing statistical bulletin from which data from 16 years sample was extracted and used. Also the Federal Inland Revenue Service and other relevant government agencies are acknowledged. 


\section{FUNDING}

There was no grant or financial support provided from any agency in the public, commercial and not for profit organization for this research work.

\section{REFERENCES}

1. Adam, M. (2009). Nigerian Banks: The challenges of adopting international financial reporting standard. Journal of international Accounting, Auditing and Taxation, 10(2), $32-45$.

2. Adereti, A.R, and Sanni, M.R. (2016). "Evaluation of the International Financial Reporting Standards' Adoption in the Nigerian Quoted Oil and Gas Industry". PhD Post-field Thesis, OAU, Ife, Nigeria.

3. Abdul-Baki, Uthman and Sanni (2014). 'The effect of IFRS adoption on the performance evaluation of a case firm". Journal of Accounting 4 (2), 2-9.

4. Ahmed, A. (2011). Practical challenges of HRS implementation, "What Bank Regulators Need To Know" (IFRS International Conference Nigeria.

5. Akinyele Samuel Taiwo and Fasogbon Olufunke Idunnu. (2010). impact of strategic planning on organizational performance and Survival. Research Journal of Business Management, Covenant University, Nigeria

6. Armstrong, C. M, Barth, A., Jagolinzer, P, and Riedl, E. (2007). "Market reaction to the adoption of IFRS in Europe". Working paper, Stanford University.

7. Bala, A.R (2013). "The effects of the adoption of IFRS on the financial reports of Nigerian listed oil and gas entities". "Journal of Accounting Research 76, 167-298.

8. Barth, M. Landsman, W.R. and Lang, M (2008). "International accounting standards and accounting quality”. Journal of Accounting Research 46, 467-498 11.

9. Bhattacharjee, S., and Hossain, M. S. (2010). Determinants of financial reporting outcomes following IFRS adoption-implications for Bangladesh, The Bangladesh Accountant, 69(40), pp. 10-19.

10. Bushman, R.M. and Piotroski, D. (2006) Financial Reporting Incentives for Conservatism Accounting: The Influence of Legal and Political Institutions. Journal of Accounting and Economics, 42, 107-148. http://dx.doi.org/10.1016/j.jacceco.2005.10.005

11. Christensen, H.B., Lee, E., and Walker, M. (2008), Incentives or Standards: What Determines Accounting Quality Changes around IFRS Adoption? Working paper, Manchester Business School.

12. Hakim Ben Othman and Anas Kossentini (2015), "IFRS adoption strategies and theories of economic development", Journal of Accounting in Emerging Economies, Vol. 5 Issue 1, pp. 70 - 121 Permanent link to this document: http://dx.doi.org/10.1108/JAEE-02-2012-0006

13. International Financial Reporting Standards (IFRS) Report, (2008)

14. Jarva, H. \& Lantto, M.A. (2012). "Information content of IFRS versus domestic accounting standards: Evidence from Finland", "The Finnish Journal of Business Economics, 2, 141-177. 
15. Leuz, C. and Verrecchia, R. (2000) “The Economic Consequences of Increased Disclosure”, Journal of Accounting Research, 38, 91-124, https://doi.org/10.2307/2672910.

16. Mike, M. (2009). Seminar Understanding IFRS. National GAAP vs. IFRS (Lagos, Nigeria,)

17. Okere, E, O. (2009). International Financial Reporting and Accounting Issues: Imperatives of Attainment of Economic Development in Nigeria, ICAN 39 Annual Accountants Conference.

18. Okpele K.E. (2012). Adoption of IFRS and financial statements effects: The perceived implications on FDI and Nigeria economy. Australian Journal of Business.

19. Onalo, A. (2014). IFRS adoption and quality of banks accounting quality, particularly emerging economies, European Journal of Business and Social Sciences.

20. Onipe, A.Y., Musa, J.Y., and Isah, S.D. (2015). "The effects of the adoption of the International Financial Standards on the financial statements of banks". Journal of Finance and Accounting

21. Paglietti, P. (2009). "Investigating the effects of the EU mandatory adoption of IFRS on accounting quality: evidence from Italy". Journal of Business and Management, 4 (12), 3-18.

22. Yahaya, A., Fagbemi, A., Balogun, N., and Raheem B., (2015) "International Financial Reporting Standards (IFRSs) adoption on the quality of financial statement of quoted banks in Nigeria" Journal of Marketing.

23. Young, D., \& Guenther, D. A. (2008). Financial reporting environments and international capital mobility, Journal of Accounting Research, 41, pp. 553-579. 